\title{
Ownership Reform, State Ownership, Corporate Governance, and Agency Costs: The Case of Chinese Listed Companies
}

\author{
Ratnam Vijayakumaran ${ }^{1}$ \\ ${ }^{1}$ Department of Financial Management, Faculty of Management Studies and Commerce, University of Jaffna, Sri \\ Lanka \\ Correspondence: Ratnam Vijayakumaran, Department of Financial Management, Faculty of Management Studies \\ and Commerce, University of Jaffna, Sri Lanka. E-mail: rvijay@univ.jfn.ac.lk
}

Received: February 4, 2019

Accepted: June 22, 2019

Online Published: June 25, 2019

doi:10.5430/rwe.v10n1p91

URL: https://doi.org/10.5430/rwe.v10n1p91

\begin{abstract}
The aim of this paper is to examine the effect of 2005-ownership reform and state ownership on the linkages between corporate governance mechanisms and agency costs for Chinese listed firms. Based on a large panel of Chinese listed firms, we find that following the reform managerial ownership, institutional shareholdings and debt financing have emerged as effective governance mechanisms to reduce agency costs only for private-controlled firms in the post reform period. Therefore, our study concludes that the effectiveness of corporate governance mechanisms differ between state and private controlled firms and state ownership still hinders effectiveness of governance mechanisms among Chinese listed firms. This study contributes to the literature on the implications of ownership reform and state ownership for corporate governance and agency costs at the firm level in transition economies.
\end{abstract}

Keywords: agency costs, state ownership, managerial ownership, debt financing, ownership reform, China

JEL Classification: D22, G32; G34; G38; G39; L25

\section{Introduction}

Chinese government successfully implemented a significant split share ownership reform in 2005-2006. The main aim of this reform was to improve the governance of listed firms, helping to solve the long standing agency conflicts characterizing these firms, and thereby reduce agency costs. As a consequence of the reform, listed companies' ownership structure has changed tremendously. In particular, a large number of non-tradable shares which were mainly held by the government and government related agents became tradable, increasing the liquidity in the capital markets. Further, government ownership has significantly declined in listed firms. Following the reform (from January 2006) Chinese corporations have been allowed to incentivize their top-management with equity shares and share options. As a consequence, managerial ownership has become an important phenomenon of listed firms in recent years. Additionally, following a series of reforms of the banking system, the governance of the Chinese financial sector has significantly improved and banks consider commercial judgment and prudence in their lending decisions (Cull \& Xu, 2005; Ayyagari, Demirguc-Kunt, \& Maksimovic, 2008; Firth Lin, Liu, \& Wong, 2009; Tsai, Chen, Lin, \& Hung, 2014). (Note 1) Recent research shows that generally, the reform helped to reduce conflicts of interests between controlling shareholders and minority shareholders as well as managers and shareholders, thus reducing agency costs (Chen, Schipper, Xu, \& Xue, 2012; Vijayakumaran, 2019).

Denis and McConell (2003) note that the context of privatization provides an interesting setting in which to examine the impacts of ownership structure on agency conflicts. In this line, in recent years, there has been an increasing interest in assessing the effects of corporate governance on various aspects of firm behavior in China (see for example, Kato \& Long, 2011; Conyon \& He, 2012; Dixon, Guariglia \& Vijayakumaran, 2017). Therefore, China provides an interesting setting to investigate the extent to which the split share structure reform and state ownership have affected the linkages between corporate governance mechanisms and agency costs for firms. For a $100 \%$ owner-managed firm, agency costs of equity are zero (Jensen \& Meckling, 1976). Yet, in modern corporations, the separation of ownership and control creates considerable agency costs not only for the owners but also the economy as a whole (Berle \& Means, 1932; Alchian \& Demsetz, 1972; Jensen \& Meckling, 1976). In their seminal work on the analysis of agency costs, Ang et al. (2000) use the asset utilization ratio and the operating expenses ratio as empirical proxies to measure agency costs, and provide direct tests of the theoretical predictions made by Jensen and 
Meckling (1976), according to which agency costs are higher for firms whose managers have less than a 100 percent ownership stake, and should decrease as the equity shareholdings of the owner-manager increase. In line with these predictions, they find an inverse relationship between inside ownership and agency costs. (Note 2)

If governance mechanisms are effective in reducing agency costs in the post reform period, then this would imply that the ownership reforms have been successful in making the governance mechanisms more effective. To this end, our study uses a large panel data of Chinese listed firms over the period 2003-2010. As our data spans the 2005-2006 split share structure reform, it enable us to look at the impact of corporate governance on the agency costs for pre-and post-reform periods as well as state and private controlled Chinese listed firms. Using the system GMM estimator to control for unobserved firm characteristics and potential endogeneity, we find that managerial ownership, institutional shareholdings and debt financing work as effective governance mechanisms in mitigating the costs of agency conflicts in Chinese listed firms. Specially, we find that these governance mechanisms help to alleviate the agency costs for private firms in the post-reform period.

Our study contributes to the existing literature in two ways. First, ours is the first study which provides empirical evidence on the effects of the 2005-split-share-structure reform on the linkages between corporate governance mechanisms and agency costs for Chinese listed firms. Second, we offer first evidence on the linkages between corporate governance mechanisms and agency costs, differentiating between state-controlled and private-controlled firms.

The remainder of the paper is organized as follows. Section 2 reviews relevant literature and develops hypotheses. The model specification and estimation method are discussed in Section 3. In Section 4, we describe the data and descriptive statistics of the variables used in this study. Section 6 presents empirical results. Finally, Section 7 concludes the paper.

\section{Literature Review and Hypotheses}

In this section, we review the literature and develop hypotheses linking agency costs and the corporate governance mechanisms including ownership structure, board structure and debt financing, by paying a particularly attention to the Chinese listed companies.

\subsection{Evidence on the Links Between Agency Costs and Ownership Based on Small and Medium-Sized Enterprises (SMEs)}

In their seminal empirical work, Ang, Cole and Lin. (2000) use the assets utilization ratio (which is measured by the sales to assets ratio), and the expenses ratio (which is measured by the operating expenses scaled by assets) as proxies to measure agency costs. They use a sample of 1,708 small corporations from the Federal Reserve Board's National Survey of Small Business Finances (NSSBF) database in their analysis. No publicly traded firm is entirely owned by management. By contrast, many of the small firms are owned solely by a single owner-manager, and, as such, the interest of the owner and the manager should be closely aligned, and therefore agency costs should be nil. Thus, small corporations provide an ideal setting for measuring agency costs for corporations under different ownership and management structures. Ang et al. (2000) analyse the impact of ownership structure and outside monitoring on measures of agency costs of firms. They find that agency costs are significantly higher in firms which are managed by an outsider rather than an insider, and are inversely associated with the manager's shareholdings in the firms. Furthermore, they find that while agency costs increase with the number of non-manager shareholders, greater monitoring of small firms by banks helps to reduce agency costs.

Similarly, Fleming, Heaney and McCosker (2005) examine the relationship between equity agency costs and ownership structure, using a sample of approximately 3800 Australian small and medium enterprises for the periods 1996-1997 and 1997-1998. Similar to Ang et al. (2000), they find that agency costs are lower in firms managed by equity-holders. However, as Fleming et al. (2005) observe, the magnitude of the agency costs are lower for Australian SMEs compared to their US counterparts. This may suggest that country-specific factors may have a role on the agency costs incurred by the firms. Fleming et al. (2005) also find that the agency costs faced by firms are inversely related to managerial and employee equity holdings. Furthermore, the authors report that the agency costs of the firm decrease as the proportion of family ownership increases, suggesting that families have unique ability to undertake effective monitoring and thus discipline managers due to their special relationships with the firm. In addition, they find that the level of parent company ownership increases the agency costs in their sample of SMEs. They attribute this result to insufficient controls exercised by parent company on the management of subsidiaries. Finally, unlike Ang et al. (2000), Fleming et al. (2005) do not find any definite relationship between the debt-to-asset ratio (which they use as a proxy for bank's incentive to monitor borrowers) and agency costs. While both of these studies provide important insight into the 
impact of ownership and bank monitoring on the agency costs, they do not examine the impact of board of management/directors on the agency costs faced by SMEs. Further, these studies do not control for potential endogeneity of ownership variables.

\subsection{Evidence on the Links Between Agency Costs, Ownership, and Internal Governance Mechanisms Based on Listed} Companies

Adopting a similar approach, but using data from large listed US-firms, Singh and Davidson (2003) extend the work of Ang et al. (2000) by examining the effects of ownership structure and other internal governance mechanisms on agency costs. They use the sales and general and administrative expenses to total assets ratio, in addition to the asset utilization ratio to measure agency costs. Singh and Davidson (2003) argue that sales and general and administrative (SG\&A) expenses are more likely to represent agency induced managerial excessive pay and perquisite consumption. The SG\&A expenses includes salaries which are an important element of total benefits flowing to firm management and may reflect managerial discretion in spending company resources. Further, the authors suggest that management can easily use advertising and selling expenses to camouflage expenditures on their perks. Therefore, higher agency conflict would be reflected in higher managerial discretionary SG\&A expenses. Similar to the results of Ang et al. (2000), they find a positive relationship between managerial ownership and asset utilization efficiency, meaning that increasing managerial ownership helps to align the interests of managers with those of the shareholders, to enhance the utilization of assets, thus reducing the agency costs arising from the separation of ownership and control in large corporations. However, their results show that managerial ownership cannot reduce excessive discretionary expenses. Furthermore, Singh and Davidson (2003) report that smaller boards are effective in reducing agency costs, while outside block ownership and outside directors are ineffective mechanisms. Although Singh and Davidson (2003) control for unobserved fixed effects using a fixed effects estimator, they do not control for the potential endogeneity of ownership and other governance variables.

Florackis (2008) investigates the impact of several corporate governance mechanisms on two alternative proxies for agency costs: the asset utilization ratio (total sales to total assets ratio) and the ratio of selling, general and administrative expenses to total sales. Departing from previous studies, his main focus is how choices of debt maturity structure affect the agency costs experienced by firms. Following Singh and Davidson (2003), he also studied a large panel of UK listed firms. Florackis (2008) finds that the capital structure characteristics of firms including bank debt and debt maturity, especially short-term debt, play an important role in mitigating agency related problems for UK firms, and thus reducing agency costs. Furthermore, he reports that managerial ownership is an important governance mechanism to mitigate agency costs of UK firms. Additionally, the author finds that, managerial compensation and ownership concentration can help UK firms mitigate agency costs. His results also show that the impact of specific internal governance mechanisms on agency costs varies with firms' growth opportunities. However, these empirical studies do not control for potential endogeneity of ownership and other governance variables.

Improving on previous studies, Florackis and Ozkan (2009) use a GMM estimator to examine the relationship between managerial entrenchment and agency costs in a panel of UK listed firms over the period 1999-2005. To measure managerial entrenchment, they develop a managerial entrenchment index utilising detailed information on ownership and board structures and managerial compensation. The aim of this exercise is to capture the extent to which managers have the ability and incentives to expropriate wealth from other shareholders. They find that managerial entrenchment is negatively associated with their inverse proxy for agency costs (i.e. asset utilization ratio), meaning that firms with high levels of managerial entrenchment experience significantly higher agency costs. They also provide evidence that short-term debt and dividend payments are important corporate governance mechanisms for UK firms, reducing the agency costs of manager-shareholder conflicts.

Finally, Wellalage and Locke (2011) study the relationship between agency costs, ownership structure and corporate governance for 100 unlisted New Zealand firms over the eleven year- period 1998-2008. Use a GMM estimation methodology, they find that insiders' ownership has the most significant effect on agency costs. More specially, they find a U-shaped relationship between insiders' ownership and agency costs consistent with the incentive alignment as well as entrenchment effects of managerial ownership.

\subsection{Evidence on the Links Between Agency Costs and the Changes to Corporate Governance Structure}

Recent empirical work focuses on how changes to corporate governance structure, and especially the introduction of new corporate governance codes, and changes to the board structure have affected the agency costs faced by firms. For example, using a panel of large UK listed companies, McKnight and Weir (2009) examine the impact of the changes in board structures that have occurred in the post-Cadbury period on agency costs experienced by these firms. They find that there has been an increasing adoption of recommendations of the Combined Code related to board structures (such 
as setting up of nomination committees, appointing majority non-executive directors in the board, and separating CEO and chair position of the board). However, the changes to board structures of UK firms that have occurred following the recommendations of the Combined Code have had little impact on agency costs. The authors also find that having a nomination committee is associated with increased agency costs, suggesting that firms incur additional costs when they adopt certain governance mechanisms. (Note 3) This finding is at odds with the recommendation of the Combined Code. The authors therefore argue that for a firm that is adopting an optimal governance structure, the appointment of an additional sub-committee may represent a move away from its optimal governance structure, resulting in significant costs to the firm. Yet, consistent with findings of previous studies the authors find that increasing board ownership as well as debt help to reduces agency costs.

In a similar vein, Henry (2010) examines the expected impact of the principles of good corporate governance and best practice recommendations which were introduced by the Australian Securities Exchange (ASX) in 2003. In contrast to McKnight and Weir (2009) whose analysis is based on ex-post settings (i.e. after firms' adoption of the UK combined code), Henry (2010) develops a 'structural' governance index which represents components of this code of governance practice now in force in Australia, and examines how firms' voluntary adoption of best corporate governance practices affects agency costs during the pre-adoption period from 1992 to 2002. His results suggest that although the adoption of individual 'structural' governance practices does not greatly affect agency costs, greater voluntary compliance with the index that represents the code of governance practice (which was later formally introduced by ASX) indeed helps in significantly reducing the level of agency costs experienced by Australian listed firms. Therefore, they conclude that Australian listed firms' increasing post-introduction compliance with the ASX Corporate Governance Council code of practice would help to lower agency-costs. The contrasting findings of these two studies may suggest that impact of governance structure may vary depending on the institutional environment in which firms operate. This warrants additional research to assess the effectiveness of corporate governance mechanisms in a different institutional setting such as the Chinese one.

\subsection{Evidence on the Links Between Agency Costs, Ownership, and Internal Governance Mechanisms in Transition/Emerging Economies}

Only a handful of papers analyse the relationship between ownership structure and internal governance mechanisms, on the one hand, and agency costs, on the other, for Chinese listed firms. Tian and Estrin (2007) examine the governance role of debt in the context of Chinese firms. Focusing on a sample of 2660 firm-year observations pertaining to Chinese public listed companies over the period 1994-1998, they provide evidence suggesting that in contrast to the corporate governance literature, the use of debt capital among Chinese listed firms increases agency costs in the form of managerial perquisites (i.e. disguised income for management teams) and discretionary expenses. This can be explained considering that the main source of debt capital for Chinese listed firms is bank loans, and an increase in bank lending increases the size of managerial perks and free cash flows, decreasing corporate efficiency. However, when the authors differentiate the governance role of the debt between state- and privately-controlled firms, they find that while bank financing facilitates managerial exploitation of corporate wealth in the former, it is negatively but insignificantly associated with agency costs in the latter. This can be explained considering that government ownership of both banks and firms and the resultant soft budget constraints make debt an ineffective governance mechanism in state-controlled firms. Yet, they do not examine how other governance mechanisms affect agency costs that firm faces.

Firth, Fung and Rui (2008) examine the relationship between ownership structure and governance mechanisms, on the one hand; and agency costs, on the other, for Chinese listed firms, focusing on a sample of 1,647 firm-year observations for 549 non-financial listed companies over the period 1998-2000. Firstly, they find that firms with foreign shareholding experience higher levels of agency costs, implying that foreign investors do not closely monitor managers' non-value maximising behavior, and that foreign ownership is associated with increased managerial discretionary/non-necessary expenditures (i.e. agency costs). Furthermore, they find no evidence that government ownership and legal person shareholding exert influence on the level of agency costs. Consistent with the findings of Western studies (for example, Singh \& Davidson, 2003; McKnight \& Weir, 2009), they also report that the composition of the board of directors (proxied by the proportion of non-executive directors) is not effective in reducing agency costs. Overall, the findings in Firth et al.'s (2008) study suggests that that ownership and governance reforms which Chinese listed firms had undergone before 2000 have not been largely effective in reducing agency costs incurred by these firms. These two studies provide valuable insight into the efficacy of ownership and other internal governance mechanisms in mitigating agency costs in the early stage of the reform process of Chinese SOEs.

More recently, Vijayakumaran (2019) examines the impact of governance mechanisms such as ownership structure 
and board characteristics and debt financing on agency cost, making use of a large panel of Chinese listed firms. He measures the agency costs in two ways: using the sales to assets ratio, and the general administration and selling expenses scaled by assets. His study finds that managerial ownership and debt financing are negatively and significantly associated with agency costs for Chinese listed firms.

\subsection{Hypotheses: Ownership Reform, State Ownership, Corporate Governance and Agency Costs}

The separation of ownership and control and the resultant misaligned incentives of managers and owners in modern corporations create agency costs, such as shirking, excessive consumption of perks, or other non-value maximising behaviour by managers (Fama \& Jensen, 1983; Jensen \& Meckling, 1976). In addition, controlling shareholders (state and non-state large shareholders) may expropriate corporate resources at the expenses of minority shareholders. Previous research argues that because of complex agency problems, Chinese government's ownership of firms leads to inefficiency and unsatisfactory firm performance (e.g. Sun and Tong, 2003; Wei, Xie, \& Zhang., 2005). In the context of China, from the early stages of the reform process, various mechanisms have been used to enhance the governance of listed firms. These mainly include managerial autonomy and a management responsibility system and corporatization and partial privatisation of former SOEs (Aivazian, Ge, \& Qiu, 2005).

In addition, government implemented a major split share ownership reform in 2005-2006. As a result of the reform, listed companies' a large number of non-tradable shares which were mainly held by the government and government related agents became tradable. This reform not only has increased the liquidity in the capital markets but also helped to reduce conflicts of interests between controlling shareholders and minority shareholders as well as managers and shareholders, thus reducing agency costs (Chen et al., 2012; Vijayakumaran, 2019). Unlike the top managers of industrialised countries, due to the government policy and constrained personal wealth, managers of Chinese listed firms historically had very low equity ownership stakes in their firms. In January 2006, the CSRC issued "The Administrative Rules of Equity Compensation of Listed Companies" which allows the companies that have successfully completed their split-share-reforms to adopt equity based compensation plans for their managers. This also provided a strong incentive for the top managers of listed companies to complete the reform at the earliest possible in order to participate in the new compensation scheme. During the last decade there has been a considerable increase in the equity ownership of managers in China especially with the implementation of 2005 ownership reform and the introduction of stock based incentive to top managers (Conyon \& He, 2011 and 2012; Walder, 2011; Vijayakumaran, 2014; Dixon et al., 2017; Vijayakumaran \& Vijayakumaran 2019). As a consequence, average managerial ownership rose from $0.5 \%$ in 2003 to $8.2 \%$ in 2010 and thus managers' interests are more likely to be aligned with stock return performance. Furthermore, the reduction in the government's share ownership and the improvement in the governance of banks have provided the Chinese commercial banks with incentive incentives to consider commercial terms when issuing loans to firms, and to closely monitor the firms to which they have provided finance.

Generally, research finds that whatever the managerial incentive system, it was associated with an improvement in the productivity and performance of firms, with limited effects in state controlled firms (Groves, Hong, McMillan \& Naughton., 1994; Chow, 1997, Kato \& Long, 2006 a, b, c). Furthermore, research on governance of Chinese listed firms suggests that government control over the firms weakens the efficacy of corporate governance mechanisms (Kato \& Long, 2006a, b, c, and 2011; Tian \& Estrin, 2007; Vijayakumaran, 2014; Dixon et al., 2017; Vijayakumaran \& Vijayakumaran, 2019). Thus, we argue that corporate governance mechanisms are more likely to work effectively to alleviate agency costs for private-controlled Chinese listed firms in the post-reform period. Therefore, we hypothesize that:

H1: The effects of corporate governance mechanisms on agency costs are larger and more prevalent in private-controlled firms compared to their state-controlled counterparts.

H2: The effects of corporate governance mechanisms on agency costs are stronger in the post-reform period.

\section{Research Design}

\subsection{Sample and Dataset}

The data used in this study are obtained from two Chinese databases, namely the China Stock Market Accounting Database (CSMAR) and Sino-fin for the period of 2003-2010. The sample is composed of publicly listed non-financial firms traded on the Shanghai and Shenzhen stock exchanges. Following the literature, we exclude financial firms from our analysis. To reduce the influence of potential outliers, we exclude observations in the one percent tails of each of the regression variables. Since we lag all our independent variables once, in our empirical analysis, we end up with a panel of 9226 firm-year observations on 1420 companies over the period 2004-2010. The 
panel has an unbalanced structure, with an average of 6 observations per firm.

\subsection{Model Specification}

Our baseline model links measures of agency costs with corporate governance factors and firm characteristics. Following previous studies (Ang et al., 2000; Singh \& Davidson, 2003; McKnight \& Weir, 2009), we initially estimate the following equation:

$$
\begin{aligned}
& A G C_{i t}=\beta_{0}+\beta_{1} \operatorname{DOS}_{i(t-1)}+\beta_{2} L E V_{i(t-1)}+\beta_{3} \operatorname{SOS}_{i(t-1)}+\beta_{4} L P S_{i(t-1)}+\beta_{5} F O W N_{i(t-1)}+\beta_{6} I_{N D I R_{i(t-l)}}+\beta_{7} \text { BSIZE }_{(t-1))} \\
& +\beta_{8} F S I Z E_{i(t-l)}+\beta_{9} F A G E_{i t}+v_{i}+v_{t}+v_{j}+v_{r}+\varepsilon_{i t}
\end{aligned}
$$

where $i$ indexes firms and $t$, years. The error term in Equation (1) is made up of five components. $v_{i}$ is a firm-specific effect; $v_{t}$, time-specific effect, which we control for by including time dummies capturing business cycle effects; $v_{j}$, an industry-specific effect, which we take into account by including industry dummies; and $v_{r}$, a region-specific effect, which we control for by including a full-set of regional dummies. Finally, $\varepsilon_{i t}$ is an idiosyncratic component. $A G C_{i t}$ indicates alternative measures of agency costs. The independent variables include proxies aimed at testing the effects of ownership and corporate governance mechanisms and other control variables proved by previous studies to be influential determinants of agency costs. All variables used in this study are defined in Table 1.

\subsubsection{Agency Costs}

Following the finance literature (e.g., Ang et al., 2000; Singh \& Devidson, 2003, among others), we measure agency costs in two ways, namely using the asset utilization ratio and the ratio of general, administrative and selling expenses to total sales (GA\&S). The asset utilization ratio, which is defined as the ratio of total sales to total assets, measures the efficiency with which management uses the firm's assets to generate sales. As inefficient assets utilization results in revenue loss to the firm, agency costs are inversely related to this ratio. The second measure of agency costs is the expense ratio, which is defined as the sum of general, administration and selling expenses (GA\&S) divided by total sales. The expenses in the numerator of this ratio are incurred by firms in relation to the organization and management of its production and operation, and to the sale of products. These expenses typically include those expenses incurred by the board of directors and the management in operating and managing the business, such as corporate cars, travelling expenses, entertainment expenses as well as other service bills. More importantly, much of these expenses are subject to managerial discretion, and, hence, a high expense ratio may indicate high agency costs for shareholders. The expense ratio is generally used as a measure of how effectively the firm's management controls expenses, including excessive perquisite consumption, and other direct agency costs.

\subsubsection{Variables of Interest}

The main focus of this study is to discern the effects of 2005-ownership reform and state ownership on agency costs faced by Chinese listed firms. Ownership variables such as legal person shareholding (LPS), state shareholding (SOS), managerial shareholding $(D O S)$ and foreign shareholding $(F O W N)$ included in the regression model to see the impact of ownership structure on agency costs. (Note 4) As for the board characteristics, we include the board size (BSIZE); and the proportion of independent directors in the board (INDIR). In addition, following finance literature, we also include leverage $(L E V)$ which is measured as the percentage of total debt to total assets. If the above corporate governance mechanisms are effective in reducing agency costs, as predicted by our hypotheses, we would expect the level of asset utilization to be positively associated with better governance, and the discretionary expenses to be negatively related with it only in private controlled firms in the post reform period. This is consistent with the idea that only the firms with strong governance structures experience lower levels of discretionary expenses and greater levels of asset utilization.

\subsubsection{Control Variables}

In line with previous studies, Equation (1) includes several additional variables that are likely to be correlated with the agency costs faced by firms. Firm size (FSIZE) (which is measured by the natural logarithm of total real sales at the firm level) and firm age (FAGE) (which is proxied by the natural logarithm of the number of years since the establishment of the firm are included as controls in the model. We control for differences in agency costs across industries in our analysis by including a set of dummy variables, one for each of the industries considered in the CSMAR B classification. We also control for any systematic differences in regional development by including regional dummies. Finally, time-specific fixed effects are accounted for by including year dummies in all specifications. 
Table 1. Measurement of variables

\begin{tabular}{|c|c|c|}
\hline Variables & Acronyms & Definition \\
\hline \multicolumn{3}{|l|}{ Dependent Variables } \\
\hline Asset utilization ratio & $A G C I$ & Ratio of total sales to total assets \\
\hline Expense ratio & $A G C I I$ & $\begin{array}{l}\text { Sum of general, administration and selling expenses } \\
(\text { GA\&S) divided by total sales }\end{array}$ \\
\hline \multicolumn{3}{|l|}{ Test variables } \\
\hline Managerial share ownership & DOS & $\begin{array}{l}\text { Percentage of shares owned by managers, directors and } \\
\text { supervisors }\end{array}$ \\
\hline Leverage ratio & $L E V$ & Ratio of total leverage to total assets \\
\hline State-owned shares & $S O S$ & $\begin{array}{l}\text { Percentage of shares owned by the central government, local } \\
\text { governments, or any entity representing the central or local } \\
\text { governments }\end{array}$ \\
\hline Legal person shares & $L P S$ & $\begin{array}{l}\text { Percentage of shares owned by non-individual legal entities } \\
\text { or institutions }\end{array}$ \\
\hline Foreign share ownership & FOWN & Percentage of shares owned by foreign investors \\
\hline Independent directors & INDIR & Proportion of independent directors on the board of directors. \\
\hline Board size & $B S I Z E$ & Total number of directors on the board \\
\hline \multicolumn{3}{|l|}{ Control Variables } \\
\hline Firm size & $F S I Z E$ & Natural logarithm of the firm's total real sales \\
\hline Firm age & $F A G E$ & $\begin{array}{l}\text { Natural Logarithm of the number of years since the } \\
\text { establishment of the firm }\end{array}$ \\
\hline Year dummies & $v_{t}$ & Year dummies for the years 2005 to 2010. \\
\hline Industry dummies & $v_{j}$ & $\begin{array}{l}\text { Dummies for the following four industrial groups based on } \\
\text { the CSMAR B classification: Properties, Conglomerates, } \\
\text { Industry, Commerce. Utilities and financial industries are } \\
\text { excluded. }\end{array}$ \\
\hline Regional dummies & $v_{r}$ & $\begin{array}{l}\text { Dummies indicating whether the firm is located in the } \\
\text { Coastal, Western, or Central region of China }\end{array}$ \\
\hline
\end{tabular}

Note: Real variables are derived from nominal ones using China's GDP deflator.

\subsection{Estimation Methodology}

To test our hypotheses, we apply the system Generalized Methods of Moments (GMM) technique developed by Arellano and Bond (1991), Arellano and Bover (1995) and Blundell and Bond (1998). This technique simultaneously controls for firm-specific fixed effects, and endogeneity problems, by using lagged values of the potentially endogenous variables as internal instruments. The system GMM estimator estimates the relevant equation both in levels and in first-differences. First-differencing is used to control for unobserved heterogeneity. We use all right-hand side variables (except age and the dummies) lagged twice or more as instruments in the first-differenced equation, and first-differences of these same variables lagged once as instruments in the level equation. Blundell and Bond (1998) point out that the first-differenced GMM procedure may suffer from weak instrument problems and might produce biased results. Therefore, to reduce the potential biases and imprecision associated with the first-differenced GMM estimator, we use the system GMM estimation.

We use the Hansen test for over identifying restrictions, and the test for second order autocorrelation of the differenced residuals (AR (2)) to test the validity of our instruments. In the case of failure of the Hanson test and/or AR (2) test, regressors lagged three times or more are included in the instrument set (Bond, 2002).

\section{Empirical Results}

In this section, we first discuss descriptive statistics and results of correlation analysis. We then discuss the results of our regression model (equation 1) which we estimate separately for the pre- and post-2006 period, and for 
state-controlled and private-controlled firms.

\subsection{Descriptive Statistics}

Table 2 reports descriptive statistics for the variables used in our analysis. We observe that the pooled mean (median) value of managerial ownership is $2.3 \%(0 \%)$, with a minimum value of $0 \%$ and maximum value of $65.4 \%$. The state and legal persons hold on average (at the median) $23.3 \%(17.3 \%)$ and $14 \%(1.2 \%)$ of the shares, respectively. Foreign shareholders, on average (at the median), hold $4 \%(0 \%)$ of total issued shares. The average (median) board size is 9.360 (9.0), with an average (median) proportion of independent outside directors of $35.2 \%(33.3 \%)$. The average (median) debt to total asset ratio is $51.3 \%(51.6 \%)$.

Table 2. Summary statistics

\begin{tabular}{lllllll}
\hline Variable & $\mathrm{N}$ & Mean & SD & P50 & Min & Max \\
\hline Asset utilization ratio $(A G C I)$ & 9226 & 0.680 & 0.445 & 0.582 & 0.036 & 2.660 \\
Expense ratio (AGCII) & 9062 & 0.155 & 0.132 & 0.119 & 0.016 & 1.285 \\
Managerial shareholding (DOS) & 8142 & 0.023 & 0.090 & 0.000 & 0.000 & 0.654 \\
Leverage to assets ratio (LEV) & 9226 & 0.513 & 0.205 & 0.516 & 0.060 & 1.677 \\
State shareholding (SOS) & 8776 & 0.233 & 0.240 & 0.173 & 0.000 & 0.750 \\
Legal person shareholding (LPS) & 8776 & 0.140 & 0.198 & 0.012 & 0.000 & 0.733 \\
Foreign shareholding (FOWN) & 8776 & 0.039 & 0.108 & 0.000 & 0.000 & 0.513 \\
Independent directors (INDIR) & 8249 & 0.353 & 0.045 & 0.333 & 0.000 & 0.545 \\
Board size (BSIZE) & 8249 & 9.360 & 1.882 & 9 & 5 & 15 \\
Firm size (billion RMB)(FSIZE) & 9226 & 1.126 & 2.103 & 0.464 & 0.019 & 19.478 \\
Firm age (FAGE) & 9226 & 11.407 & 4.045 & 11.000 & 1.000 & 28.000 \\
\hline
\end{tabular}

Notes: This table reports summary statistics of the main variables used in our study. Sd indicates the standard deviation; $\mathrm{N}$, the number of observations; p50, the median; min, the minimum value; and max, the maximum value. All variables are defined in Table 1 in the Appendix.

As for the control variables included in our baseline model, the average (median) firm size is just over 1 billion RMB (0.464), and the average (median) firm age measured by number of years from the establishment of firm is 11.41 (11). (Note 5) Average (median) productivity, measured as real sales per employee, is 0.55 million RMB (0.24). Table 3 presents the Pearson correlation coefficients between variables. Since corporate governance mechanisms are highly likely to be endogenous, we do not concentrate much on the interpretation of correlation coefficients. Nonetheless, Table 3 suggests that, since the correlation coefficients between the independent variables are relatively low, multicollinearity should not be a serious problem in our study.

\subsection{Agency Costs for State and Non-state Firms}

We now investigate how the impact of ownership and governance mechanisms on agency costs differs between the subsamples of state and non-state firms classified based on controlling owner. For this purpose we first use the asset utilization ratio to measure agency costs. In Columns 1 and 2 of Table 3, we provide separate GMM estimates of the equation (1) for non-state and state firms, respectively. The results show that the coefficient of managerial ownership $(D O S)$ is positive and significant at the $1 \%$ level for private controlled firms, whilst it is poorly determined for state firms, suggesting that managerial ownership is only effective in reducing agency costs at non-state firms. This result is consistent with the findings of Conyon and $\mathrm{He}(2011,2012)$, and Kato and Long (2006 a,b,c and 2011).

The coefficients associated with state shareholdings $(S O S)$ are insignificant at conventional levels for both state- and non-state -controlled firms. Interestingly, the estimated coefficient of legal person shareholders (Institutional shareholders) (LPS) is positive and significant at $10 \%$ level only for privately-controlled firms, indicating that privately controlled institutional shareholders such as mutual funds in privately controlled firms closely monitor managers, thus reducing agency costs. This result is consistent with Bhabra, Liu, \& Tirtiroglu (2008), who show that legal person shareholders in privately controlled firms helps to improve corporate governance by encouraging managers to use more debt financing, which is an important device to constrain inappropriate use of free cash flow. 
Table 3. Ownership reform, state ownership, corporate governance and agency costs

\begin{tabular}{|c|c|c|c|c|}
\hline \multicolumn{5}{|c|}{ System GMM } \\
\hline & $\begin{array}{c}\text { Non-state } \\
\text { (1) }\end{array}$ & $\begin{array}{l}\text { State } \\
(2)\end{array}$ & $\begin{array}{c}\text { Pre-reform } \\
\text { (3) }\end{array}$ & $\begin{array}{c}\text { Post- reform } \\
\text { (4) }\end{array}$ \\
\hline \multicolumn{5}{|c|}{ Corporate governance variables } \\
\hline \multirow[t]{2}{*}{$\operatorname{DOS}_{i(t-1)}$} & $0.639^{* * *}$ & 0.540 & 0.754 & $0.464^{* *}$ \\
\hline & $(0.190)$ & $(0.797)$ & $(0.507)$ & $(0.183)$ \\
\hline \multirow[t]{2}{*}{$\operatorname{SOS}_{i(t-1)}$} & 0.142 & 0.018 & -0.023 & 0.074 \\
\hline & $(0.099)$ & $(0.063)$ & $(0.373)$ & $(0.053)$ \\
\hline \multirow[t]{2}{*}{$L P S_{i(t-1)}$} & $0.112^{*}$ & 0.092 & -0.061 & $0.108^{*}$ \\
\hline & $(0.062)$ & $(0.078)$ & $(0.202)$ & $(0.061)$ \\
\hline \multirow[t]{2}{*}{$F O W N_{i(t-1)}$} & -0.315 & 0.394 & $-1.608^{* * *}$ & -0.144 \\
\hline & $(0.338)$ & $(0.368)$ & $(0.461)$ & $(0.281)$ \\
\hline \multirow[t]{2}{*}{$I N D I R_{i(t-I)}$} & -0.031 & -0.105 & -0.118 & 0.213 \\
\hline & $(0.675)$ & $(0.359)$ & $(0.718)$ & $(0.433)$ \\
\hline \multirow[t]{2}{*}{$B S I Z E_{(t-1)}$} & -0.048 & $-0.413^{* * *}$ & -0.313 & -0.144 \\
\hline & $(0.199)$ & $(0.143)$ & $(0.273)$ & $(0.137)$ \\
\hline \multirow[t]{2}{*}{$L E V_{i(t-l)}$} & $0.152^{*}$ & 0.168 & $-0.252^{*}$ & $0.224^{*}$ \\
\hline & $(0.082)$ & $(0.153)$ & $(0.144)$ & $(0.123)$ \\
\hline \multicolumn{5}{|l|}{ Control variables } \\
\hline \multirow[t]{2}{*}{$F S I Z E_{i(t-1)}$} & $0.189^{* * *}$ & $0.189^{* * *}$ & $0.309^{* * *}$ & $0.132^{* * *}$ \\
\hline & $(0.030)$ & $(0.025)$ & $(0.041)$ & $(0.019)$ \\
\hline \multirow[t]{2}{*}{$A G E_{i t}$} & 0.031 & $-0.076^{*}$ & -0.011 & -0.024 \\
\hline & $(0.043)$ & $(0.045)$ & $(0.071)$ & $(0.041)$ \\
\hline Regional dummies & yes & yes & yes & yes \\
\hline Industry dummies & yes & yes & yes & yes \\
\hline Year dummies & yes & yes & yes & yes \\
\hline Observations & 2856 & 5448 & 3418 & 5037 \\
\hline Hansen test ( $p$ values) & $11.21(0.426)$ & $12.14(0.353)$ & $16.59(0.121)$ & $14.66(0.329)$ \\
\hline$A R 1$ ( $p$ values) & $-6.48(0.000)$ & $-6.32(0.000)$ & $-3.99(0.000)$ & $-7.77(0.000)$ \\
\hline$A R 2$ ( $p$ values) & $\begin{array}{c}-1.27 \\
(0.202)\end{array}$ & $-1.47(0.143)$ & $-0.84(0.476)$ & $-0.62(0.532)$ \\
\hline
\end{tabular}

Notes: The dependent variable in all columns is agency costs measured using the asset utilization ratio. All equations are estimated using a system GMM estimator. AR1 (AR2) is a test for first- (second-) order serial correlation of the differenced residuals, asymptotically distributed as $N(0,1)$ under the null of no serial correlation. The Hansen $J$ test of over-identifying restrictions is distributed as Chi-square under the null of instrument validity. We treat all right-hand side variables except firm age as potentially endogenous: levels of these variables dated $t-2$ and further are used as instruments in the first-differenced equations and first-differences of these same variables lagged once are used as additional instruments in the level equations. Regional, industry, and time dummies are always included in the instrument set. Standard errors are in parentheses. ***, **, and * denote significance levels of $1 \%, 5 \%$ and $10 \%$, respectively. See Table 1 for definitions of all variables.

The estimated coefficient of board size (BSIZE) is negative and significant at the $1 \%$ level only for state-controlled firms, suggesting that larger boards are associated with higher agency costs. This result is consistent with the findings with Huyghebaert and Wang (2012) for Chinese SOEs. The authors suggest that board size does not influence related party transactions, but is associated with larger labour redundancies in Chinese SOEs. (Note 6) This 
result can also be explained considering that almost $90 \%$ of the board members of the state controlled listed firms are government officials who are likely to pursue social and political objectives, resulting in higher agency costs for minority shareholders (Su, 2005).

The coefficient of debt financing ( $L E V$ ) indicating that, similar to managerial ownership, debt financing is only effective in reducing agency costs at non-state firms. This result is consistent with Ding, Guariglia and Knight, (2014) who show that debt contributes positively to the investment efficiency of private firms, but not to that of state owned enterprises (SOEs). This implies that the preferential lending to the state sector by the banking system may still be problematic.

As for the effects of control variables, the results show that in all specifications, the estimated coefficient on firm size (FSIZE) is positive and significant at the $1 \%$ level, suggesting that larger firms are associated with lower agency costs. This is consistent with the prediction that large firms have more resources, experience economies of scale, and are able to effectively monitor managers' misconduct. This result is also consistent with Ang et al. (2000), Singh and Davidson, (2003) and Firth et al. (2008) among others. The coefficient associated with firm age (FAGE) is negative and statistically significant at the $10 \%$ level in only in state controlled firms. This finding is consistent with our prediction that Chinese older firms are more likely to be former SOEs with a long history of operation (which were then converted into listed companies), and as such face more agency problem leading to less efficient utilization of assets and higher agency costs. This result is also consistent with the findings of Tian and Estrin (2007) and Firth et al. (2008). Overall, the results show that managerial ownership, institutional shareholders, and debt financing are only effective in reducing agency costs only for non-state firms.

\subsection{Agency Costs in the pre- and Post-2005 Reform Period}

Columns 3 and 4 of Table 3 provide separate estimates of Equation (1) for the pre- and post-2006 period, respectively. Focusing on column 3, we observe that, in the pre-reform period, the coefficients on foreign ownership and debt financing are negative and significant at conventional levels, suggesting that both foreign ownership and leverage are associated with high levels of agency costs. These results are consistent with the findings of Firth et al. (2008) and Tian and Estrin (2007) respectively. The negative coefficient on leverage suggests that prior to the stock market and banking reforms, Chinese banks were less efficient in monitoring their borrowers, leading bank debt to facilitate wasteful investment which increased agency costs. Similarly, before the reform, foreign shareholders were not effective in monitoring of management, but, instead, encouraged managers' consumption of perks. Other corporate governance variables are not significant at conventional levels.

Turning to the results for the post-2005 reform period in Column 4 of Table 3, we observe that the coefficients associated with managerial ownership (DOS), and debt financing $(L E V)$ are positive and significant at conventional levels in the post-reform period. These results suggest that, in the post-reform period, managerial ownership and bank monitoring of borrowers through leverage work as effective governance devises, providing incentive to managers to refrain from non-value maximizing activities, reducing therefore agency costs faced by the firms. Similar findings are reported by Sarkar and Sakar (2007), who show that in the early period of institutional change in India, debt financing did not work as a disciplining device in either standalone or group affiliated firms, but it has become an important mechanism in constraining managers' opportunistic behaviour in the later period when institutions has become more market oriented.

Interestingly, in column 4 of Table 3, we also note that the coefficient of legal person ownership (LPS), which is negative and insignificant in the pre-reform period, becomes positive and significant at the $10 \%$ level after the 2005 ownership reform. This suggests a monitoring role of legal person shareholders, and can be explained in the light of the alignment of the incentives of large shareholders with those of minority shareholders that followed the reform. This may have happened because, after the reform, non-tradable shares have become tradable in the two stock exchanges. This has given the legal shareholders the incentive not only to stop expropriating corporate resources (Chen et al. 2012), but also to closely monitor managers' misconducts.

Another interesting finding from the post-reform period results is that the estimated coefficient on foreign shareholders becomes insignificant, though still negative. We do not have any convincing explanation for this result but this might be due to the fact that with the general improvement in the corporate governance of Chinese listed firms, foreign shareholders may have increased their monitoring incentives in line with the expectation of future growth potential of the firms.

The AR3 and Hansen tests generally indicate that our models are correctly specified and that the instruments are generally valid. (Note 7) 
Finally, as a robustness test, we also estimate our regression model with the ratio of general, administrative and selling expenses to total sales (GA\&S) as a proxy for agency costs instead of asset utilisation ratio. We find our results are qualitatively similar to those reported in Table 3.

Overall, our results indicate that managerial ownership, institutional ownership, and debt financing have emerged as governance mechanisms that help to mitigate agent costs among privately-controlled listed firms in the post reform period in China.

\section{Conclusions}

During the last decade there have been significant changes in the ownership and governance structure of listed firms with a view to mitigate agency conflicts, and thereby enhance efficiency and profitability in these firms. This study investigates the effects of 2005-ownership reform and state ownership on the linkages between corporate governance mechanisms and agency costs for Chinese listed companies. Through the 2005 split share structure reform non-tradable shares were floated in the open markets and following which restrictions on managerial stock ownership were removed. Prior research suggest that this reform helped to reduce conflicts of interests between controlling shareholders and minority shareholders as well as managers and shareholders, thus significantly reducing agency costs.

In this study, we analyse the a large panel of listed Chinese firms over the period 2003-2010, distinguishing the effects of governance mechanisms on agency costs between state-controlled and privately-controlled firms, as well as between the pre and post-2005 split share structure reform period. Applying the system GMM estimator, we find that managerial ownership, legal person shareholdings and debt financing work as effective corporate governance mechanisms in mitigating agency costs for the firms. In particular, we find that the beneficial effects of managerial ownership, legal person shareholdings and debt financing mainly operate in the latter part of the sample period. We also find that that managerial ownership, legal person shareholdings and debt financing are only effective in reducing agency costs at non-state firms. Furthermore, whilst the proportion of independent directors and board size generally do not affect agency costs in Chinese listed firms, larger boards are associated with higher agency costs in state-controlled firms.

Our research has significant policy implications. First, the Chinese government's recent policies aimed to reform firms' ownership structure and encourage managerial ownership in listed firms have been successful. Yet, these positive effects of managerial ownership are mainly seen in non-state firms. This is consistent with our data which show that managerial ownership has increased significantly only in private-controlled firms, and suggests that managerial ownership should be further encouraged in the state-controlled sector. This can be addressed through optimal incentive contract systems. Second, our study shows that state ownership hinders effectiveness of governance mechanisms in alleviating agency costs in state-controlled firms. Taken together, these pieces of evidence suggest that the considerable government ownership which still characterizes the majority of Chinese listed firms should be further reduced so as to increase operational efficiency (which reduces agency costs). Third, China's banking sector reform has been successful in terms of improving lending and monitoring efficiency of the banks, especially after 2005. This suggests that the removal of much of the restriction on foreign banks as per WTO accession agenda, and the listing of state owned banks have been positive developments. Finally, our findings also suggest that companies should be encouraged to have smaller boards and to pay particular attention to the quality of the independent directors in their boards. In this study we focused on the listed firms. Future research may analyse the extent to which ownership structure affects the agency costs of non-listed firms.

\section{References}

Aivazian, V. A., Ge, Y., \& Qiu, J. (2005). Can corporatization improve the performance of state-owned enterprises even without privatization?. Journal of Corporate Finance, 11, 791-808. https://doi.org/10.1016/j.jcorpfin.2004.11.001

Alchian, A. A., \& Demsetz, H. (1972). Production, information costs, and economic organization. The American Economic Review, 62(5), 777-795. Retrieved from https://www.jstor.org/stable/1815199

Ang, J. S., Cole, R. A., \& Wuh Lin, J. (2000). Agency costs and ownership structure. Journal of Finance, 55(1), 81-106. https://doi.org/10.1111/0022-1082.00201

Arellano, M., \& Bond, S. (1991). Some tests of specification for panel data: Monte Carlo evidence and an application to employment equations. Review of Economic Studies, 58, 277-297. https://doi.org/10.2307/2297968 
Arellano, M., \& Bover, O. (1995). Another look at the instrumental-variable estimation of error-components models. Journal of Econometrics, 68, 29-52. https://doi.org/10.1016/0304-4076(94)01642-D

Ayyagari, M., Demirguc-Kunt, A., \& Maksimovic, V. (2008). How well do institutional theories explain firms' perceptions of property rights?. Review of Financial Studies, 21(4), 1833-1871. http://dx.doi.org/10.2139/ssrn.668962

Bai, C., \& Xu, L. (2002). The system of incentives for CEOs with multitasks: theory and evidence from Chinese state-owned enterprises. Mimeo, World Bank, Washington, DC.

Bai, C., Li, D. D., Tao, Z., \& Wang, Y. (2000). A multi-task theory of the state-enterprise reforms. Journal of Comparative Economics, 28(4), 716-738. https://doi.org/10.1006/jcec.2000.1681

Berle, A. A., \& Means, G.C. (1932). The Modern corporation and private property. New York: Macmillan Publishing Co.

Bhabra, H. S., Liu, T., \& Tirtiroglu, D. (2008). Capital structure choice in a nascent market, evidence from listed firms in China. Financial Management, 37, 341-364. https://doi.org/10.1111/j.1755-053X.2008.00015.x

Blundell, R., \& Bond, S. (1998). Initial conditions and moment restrictions in dynamic panel data models. Journal of econometrics, 87(1), 115-143. https://doi.org/10.1016/S0304-4076(98)00009-8

Bond, S. (2002). Dynamic panel data models: a guide to micro data methods and practice. Portuguese Economic Journal, 1, 197-222. https://doi.org/10.1007/s10258-002-0009-9

Chen, Q., Chen, X., Schipper, K., Xu, Y., \& Xue, J. (2012). The sensitivity of corporate cash holdings to corporate governance. Review of Financial Studies. https://doi.org/10.1093/rfs/hhs099

Chow, G. (1997). Challenges of China's economic system for economic theory. American Economic Review, 87(2), 321-327. https://www.jstor.org/stable/2950939

Conyon, M., \& He, L. (2011). Executive compensation and corporate governance in China. Journal of Corporate Finance, 17, 1158-1175. https://doi.org/10.1016/j.jcorpfin.2011.04.006

Conyon, M., \& He, L. (2012). CEO compensation and corporate governance in China, Corporate governance. An International Review, 20(6), 575-592. https://doi.org/10.1111/j.1467-8683.2012.00935.x

Cull, R., \& Xu, L.C. (2005). Institutions, ownership, and finance. The determinants of profit reinvestment among Chinese firms. Journal of Financial Economics, 77, 117-146. https://doi.org/10.1016/j.jfineco.2004.05.010

Denis, D., \& McConnell, J. (2003). International corporate governance. Journal of Financial \& Quantitative Analysis, 38(1), 1-36. https://doi.org/10.2307/4126762

Ding, S., Guariglia A., \& Knight, J. (2014). Does China overinvest? Evidence from a panel of Chinese firms. Mimeograph, University of Birmingham.

Dixon, R., Guariglia. A., \& Vijayakumaran, R. (2017). Managerial ownership, corporate governance and Firms' exporting decisions: Evidence from Chinese listed companies. European Journal of Finance, 23(7-9), 815-853. https://doi.org/10.1080/1351847X.2015.1025990

Fama, E., \& Jensen, M. (1983). Separation of ownership and control. Journal of Law and Economics, 26(1), 301-326. https://doi.org/10.1086/467037

Firth, M., Fung, P., \& Rui, O. M. (2008). Ownership, governance mechanisms, and agency costs in China's listed firms. Journal of Asset Management, 9(2), 90-101. https://doi.org/10.1057/jam.2008.13

Firth, M., Lin, C., Liu, P., \& Wong, S. M. (2009). Inside the black box: Bank credit allocation in China's private sector. Journal of Banking \& Finance, 33(6), 1144-1155. https://doi.org/10.1016/j.jbankfin.2008.12.008

Fleming, G., Heaney, R., \& McCosker, R. (2005). Agency costs and ownership structure in Australia. Pacific-Basin Finance Journal, 13, 29-52. https://doi.org/10.1016/j.pacfin.2004.04.001

Florackis, C. (2008). Agency costs and corporate governance mechanisms: evidence for UK firms. International Journal of Managerial Finance, 4(1), 37-59. https://doi.org/10.1108/17439130810837375

Florackis, C., \& Ozkan, A. (2009). The impact of managerial entrenchment on agency costs: an empirical investigation using UK panel data. European Financial Management, 15(3), 497-528. https://doi.org/10.1111/j.1468-036X.2007.00418.x

Groves, T., Hong, Y., McMillan, J., \& Naughton, B. (1994). Autonomy and incentives in Chinese state enterprises. 
Quarterly Journal of Economics, 109, 181-209. https://doi.org/10.2307/2118432

Henry, D. (2010). Agency costs, ownership structure and corporate governance compliance: A private contracting perspective. Pacific-Basin Finance Journal, 18, 24-46. https://doi.org/10.1016/j.pacfin.2009.05.004

Huyghebaert, N., \& Wang, L. (2012). Expropriation of minority investors in Chinese listed firms: The role of internal and external corporate governance. Corporate governance: An International Review, 20(3), 308-332. https://doi.org/10.1111/j.1467-8683.2012.00909.x

Jensen, M., \& Meckling, W. (1976). Theory of the firm: Managerial behavior, agency costs and ownership structure. Journal of Financial Economics, 3(4), 305-60. https://doi.org/10.1016/0304-405X(76)90026-X

Kato, T., \& Long, C. (2006a). CEO turnover, firm performance, and enterprise reform in China: Evidence from micro data. Journal of Comparative Economics, 34, 796-817. https://doi.org/10.1016/j.jce.2006.08.002

Kato, T., \& Long, C. (2006b). Executive compensation, firm performance, and corporate governance in China: Evidence from firms listed in the Shanghai and Shenzhen stock exchanges. Economic Development and Cultural Change, 54, 945-983. https://doi.org/10.1086/503583

Kato, T., \& Long, C. (2006c). Executive turnover and firm performance in China. American Economic Review, 96, 363-367.

Kato, T., \& Long, C. (2011). Tournaments and managerial incentives in China's listed firms: New evidence. China Economic Review, 22(1), 1-10. https://doi.org/10.1016/j.chieco.2010.08.001

Li, K., Wang, T., Cheung, Y. L., \& Jiang, P. (2011). Privatization and risk sharing: Evidence from the split share structure reform in China. Review of Financial Studies, 24, 2499-525. https://doi.org/10.1093/rfs/hhr025

McKnight, P.J., \& Weir, C. (2009). Agency costs, corporate governance mechanisms and ownership structure in large UK publicly quoted companies: a panel data analysis. Quarterly Review of Economics and Finance, 49, 139-158. https://doi.org/10.1016/j.qref.2007.09.008

Megginson, W., Nash, R., Randenborgh, \& Van, M. (1994). The financial and operating performance of newly privatized firms: An international empirical analysis. Journal of Finance, 49(2), 403-452. https://doi.org/10.1111/j.1540-6261.1994.tb05147.x

Sarkar, J., \& Sarkar, S. (2008). Debt and corporate governance in emerging economies: Evidence from India. Economics of Transition, 16(2), 293-334. https://doi.org/10.1111/j.1468-0351.2008.00307.x

Shleifer, A., \& Vishny, R. (1994). Politicians and firms. Quarterly Journal of Economics, 109, 995-1025. https://doi.org/10.2307/2118354

Singh, M., \& Davidson, W.N. (2003). Agency costs, ownership structure and corporate governance mechanisms. Journal of Banking and Finance, 27, 793-816. https://doi.org/10.1016/S0378-4266(01)00260-6

$\mathrm{Su}$, D. (2005). Corporate finance and state enterprise reform in China. China Economic Review, 16, 118-148. https://doi.org/10.1016/j.chieco.2004.09.003

Sun, Q., \& Tong, W. (2003). China share issue privatization: The extent of its success. Journal of Financial Economics, 70, 183-222. https://doi.org/10.1016/S0304-405X(03)00145-4

Tian, L., \& Estrin, S. (2007). Debt financing, soft budget constraints, and government ownership: evidence from China, Economics of Transition, 15(3), 461-481. https://doi.org/10.1111/j.1468-0351.2007.00292.x

Tsai, Y. J., Chen, Y. P., Lin, C. L., \& Hung, J. H. (2014). The effect of banking system reform on investment-cash flow sensitivity: Evidence from China. Journal of Banking \& Finance, 46, 166-176.

Vijayakumaran, R. (2014). Corporate governance and corporate finance: evidence from Chinese listed companies, Unpublished doctoral dissertation. Durham University, Durham.

Vijayakumaran, R. (2017). Capital structure decisions and corporate performance: Evidence from Chinese listed industrial firms. International Journal of Accounting \& Financial Reporting, 7(2), 562-576. https://doi.org/10.5296/ijafr.v7i2.

Vijayakumaran, R. (2019). Agency costs, ownership, and internal governance mechanisms: evidence from Chinese listed companies. Asian Economic and Financial Review, 9(1), 133-154. https://doi.org/10.18488/journal.aefr.2019.91.133.154.

Vijayakumaran, R., \& Vijayakumaran, S. (2017). Institutional reforms and development of corporate governance and 
banking system in China. Asian Journal of Finance \& Accounting, 9(2), 352-368. https://doi.org/10.5296/ajfa.v9i2.12382

Vijayakumaran, R., \& Vijayakumaran, S. (2019). Leverage, debt maturity, corporate performance: Evidence from Chinese listed companies. Asian Economic and Financial Review, 9(4), 491-506. https://doi.org/10.18488/journal.aefr.2019.94.491.506

Walder, A. (2011). From control to ownership: China's managerial revolution. Management and Organization Review, 7(1), 19-38. https://doi.org/10.1111/j.1740-8784.2009.00171.x

Wei, Z., Xie, F., \& Zhang, S. (2005). Ownership structure and firm value in China's privatized firms: 1991-2001. Journal of Finance and Quantitative Analysis, 40(1), 87-108. Retrieved from https://www.jstor.org/stable/27647187

\section{Notes}

Note 1. For instance, reforms in the banking sector involved the introduction of foreign ownership and management in Chinese banks and particularly, state owned commercial banks; as well as the listing of these banks in stock exchanges. See Vijayakumaran and Vijayakumaran (2017) for a detailed discussion of China's banking system reform.

Note 2. Singh and Davidson (2003) extend the work of Ang et al. (2000) to a sample of large listed US-corporations, and others researchers, to other economic settings such as the UK and Australia (e.g., Singh and Davidson, 2003; Fleming et al., 2005; Florakis, 2008; McKnight and Weir, 2009; Hentry, 2010).

Note 3. The main function of the nomination committee is to ensure that the board of directors (executive as well as non-executive) is appointed based on merit rather than by patronage. The Combined Code recommend that firms should setup sub-committees so as to ensure transparency within the process of appointing new directors

Note 4. All shareholding variables are calculated as the percentage of shares owned by various agents. We also estimated alternative specifications, which included the squares of Managerial, state, legal person, and foreign ownership, but these quadratic terms were never statistically significant. The results are not reported for brevity, but available upon request.

Note 5. It should be noted that although firm size is measured as the logarithm of total real sales in the regression analysis, the figures reported in the descriptive statistics Table are not in logarithms as actual values are easier to interpret.

Note 6. This result is also consistent with the arguments and empirical evidence in Bai, Li, Tao, \& Wang (2000) and Bai and $\mathrm{Xu}$ (2002), who show that the chief executive officer of a SOE typically faces multiple tasks (i.e. profitability, political and social objectives). Shleifer and Vishny (1994) also note that maintaining employment is an important agenda for SOEs.

Note 7. We report the $\operatorname{AR}(3)$ test instead of the $\operatorname{AR}(2)$ test because, all instruments are lagged three or more times. 